\title{
BAPEN Malnutrition Universal Screening Tool in Adults in the City of Vlora, Albania
}

\author{
Brunilda Subashi ${ }^{1}$ \\ ${ }^{1}$ Atlantic International University
}

\begin{abstract}
\section{$>$ Introduction:}

Malnutrition, in all its forms, is a global problem and continues to be one of the greatest challenges facing our generation. 'MUST' is a five-step screening tool to identify adults, who are malnourished, at risk of malnutrition (undernutrition), or obese.
\end{abstract}

\section{$>$ Purpose:}

Evaluation of BMI, malnutrition and percentage of weight loss in the city of Vlora, Albania.

\section{$>$ Methodology:}

This is an exploratory study, carried out in the city of Vlora during May 20 - June 20, 2020, using the 'MUST' since data such as: height, weight and weight before 3-6 months, was obtained through the AFQPHALS Survey (Adult Food Quality and Physical Activity Level Survey), which was distributed online on social networks during May 17- 27, 2020 and completed by 545 adult subjects 18 years and older, including some Albanian cities with the predominance of the city of Vlora.

\section{$>$ Results \& conclusions:}

Vlora constitute $55 \%$ part of the study sample; women $75 \%$; with higher education $45 \%$ and master's degree 29\%; full-time employees $38 \%$ and students $35 \% ; 24 \%$ overweight, $9 \%$ obesity and $8 \%$ underweight; $73 \%$ has low risk, $\mathbf{1 6 \%}$ has medium risk and $11 \%$ has high risk for malnutrition; $73 \%$ has not lost weight $(0 \%)$. The high risk for malnutrition prevails in gender female, at higher education and master's level in students and full-time employees.

\section{$>$ Recommendations:}

Recognition and use of the Malnutrition Universal Screening Tool by the community, that is a free tool, easy and accessible for all to know and reduce malnutrition.

Keywords:- MUST, malnutrition, self- screening, Vlora, Albania.

\section{LITERATURE REVIEW - MALNUTRITION}

Malnutrition is one of the most serious threats to human health, as it is estimated to afflict more than half of the world population.(WHO, 1963)

The term 'malnutrition' refers to the deficiencies, excesses, and imbalances of a person's calorie and nutrient intake. (WHO, 2018)

In all its forms, malnutrition encompasses malnutrition (wasting, stunting, and underweight), vitamin or mineral imbalances, overweight, obesity, and diet-related noncommunicable diseases. (WHO, 2020)

Malnutrition is one of the world's most serious problems in development and the least attention has been paid to it. It has enormous human and economic costs, which mainly affect the poor, women and children.(BancoMundial, 2018)

Malnutrition is defined as an abnormal physiological condition caused by insufficient, unbalanced, or excessive consumption of the macro nutrients that provide dietary energy (carbohydrates, proteins, and fats) and the micronutrients (vitamins and minerals) that are essential for growth and physical and cognitive development. (FAO, 2014)

Malnutrition encompasses three broad groups of conditions:

$>$ malnutrition, which includes emaciation (insufficient weight for height), stunting (insufficient height for age) and underweight (insufficient weight for age);

$>$ micronutrient-related malnutrition, which includes micronutrient deficiencies (lack of important vitamins or minerals) or excess micronutrients;

$>$ overweight, obesity, and diet-related non-communicable diseases (such as heart disease, diabetes, and some cancers). (WHO, 2018)

Malnutrition has three defining characteristics:

- It can take various forms, including malnutrition (including wasting, stunting, and micronutrient deficiencies), and being overweight, obese, or foodrelated non-communicable diseases. This is what is known as "the double burden of malnutrition." 
It is ubiquitous, because malnutrition, in all its forms, is found everywhere and often coexists in individuals, households, communities and countries.

$>$ It has immediate consequences, which last a lifetime and are transmitted between generations. Thus, it compromises the development of individuals, communities and nations. (OMS, 2019)

Around the world, one in three people suffers from some type of malnutrition. It is not that hunger affects people in poor countries, or that obesity is a problem for people in rich countries: it is that malnutrition, in all its forms, is a global problem.

Malnutrition in all its forms is a global problem and continues to be one of the great challenges of our generation, and unhealthy diets are also among the leading causes of mortality and disability.(DA SILVA, 2016)

The tragic consequences of malnutrition include death, disabilities, delayed mental and physical development, and, as a result, delayed national socioeconomic development. (WHO, FAO, 2003)

Combating all forms of malnutrition is one of the biggest health problems worldwide.

\section{MALNUTRITION IN ALBANIA}

Lifestyle-related factors are estimated to be responsible for more than $70 \%$ of the total disease burden in Albania.

In Albania, the three most important risk factors in terms of proportion contributing to the burden of disease are unhealthy diet, high blood pressure and smoking.

The unhealthy diet causes approximately $22 \%$ of all healthy years to be lost due to death or diseases related to chronic diseases, or a total of approximately 4,400 years lost per 100,000 inhabitants.
This risk factor includes individual behaviors that range from excessive calorie consumption to dangerous components of the diet, such as salt, unsaturated fats, processed meats, lack of fruits, vegetables, or trans fatty acids. (Ministria e Shendetesise, 2017)

\section{BAPEN MALNUTRITION UNIVERSAL SCREENING TOOL}

'MUST' is a five-step screening tool to identify adults, who are malnourished, at risk of malnutrition (undernutrition), or obese. (BAPEN)

This screening tool is based on the 'Malnutrition Universal Screening Tool' ('MUST'), a validated nutrition screening tool developed by BAPEN to help identify adults at risk of undernutrition and the need for dietary advice. (BAPEN)

It is the most commonly used screening tool in the UK and is suitable for use in hospitals, community and other care settings. (NHS)

Ease of use, time to self-screen and prevalence of malnutrition were also assessed. (Abbie L. Cawood, 2018)

All you need to do is to enter your current weight and your height in the calculator below and then enter the weight you were $3-6$ months ago before you became ill or lost weight. (BAPEN)

The web-based Tool, which is free to use, is designed to help adults living in the community to identify their own risk of malnutrition. It is based on weight status and history of weight loss. (BAPEN, 2018)

It also includes management guidelines which can be used to develop a care plan. It is for use in hospitals, community and other care settings and can be used by all care workers. (BAPEN)

This tool can be completed electronically using the on line 'MUST' calculator or manually as outlined below: 


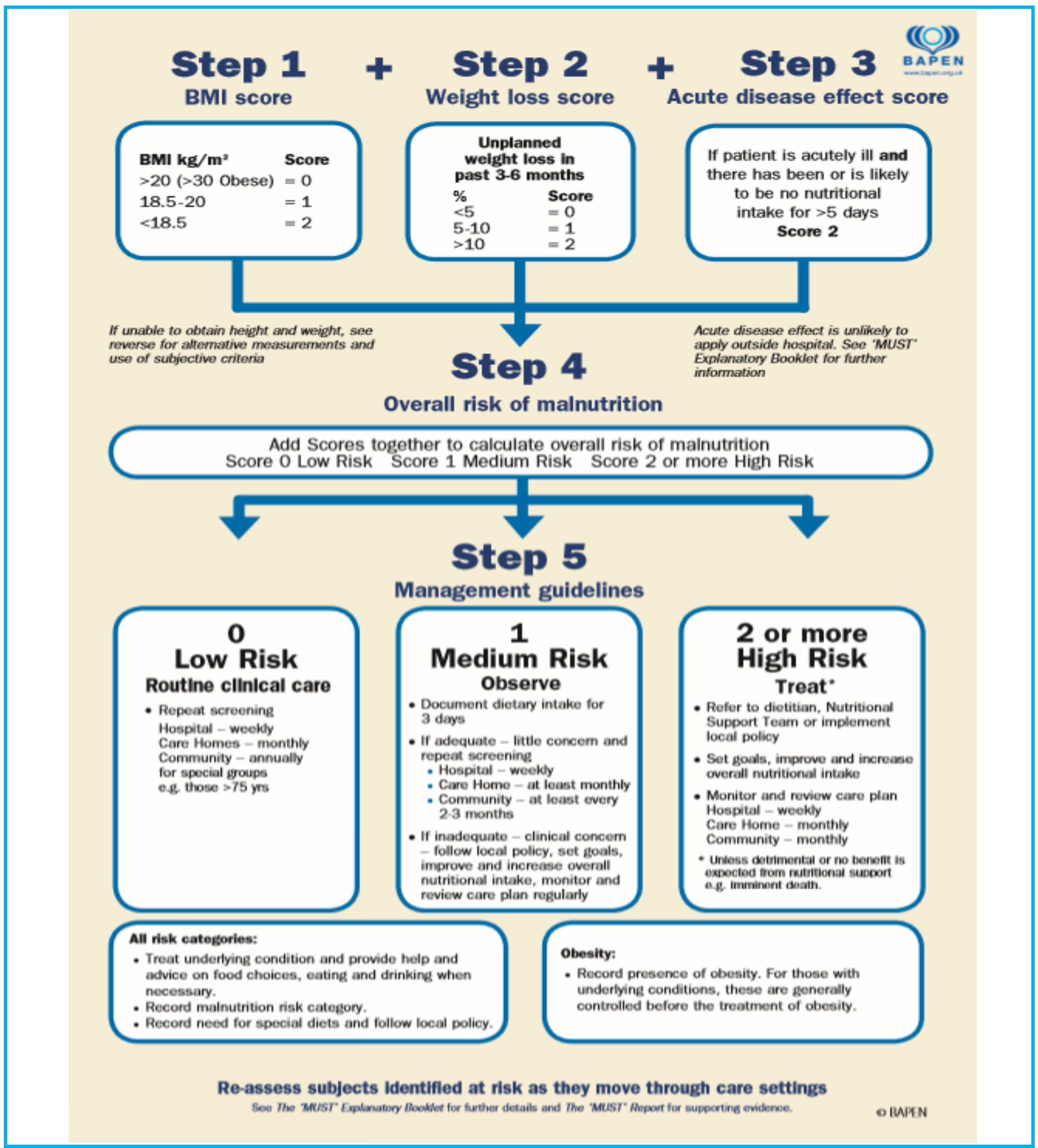

(NHS)

Fig 1:- Manually 'MUST' Flowchart 


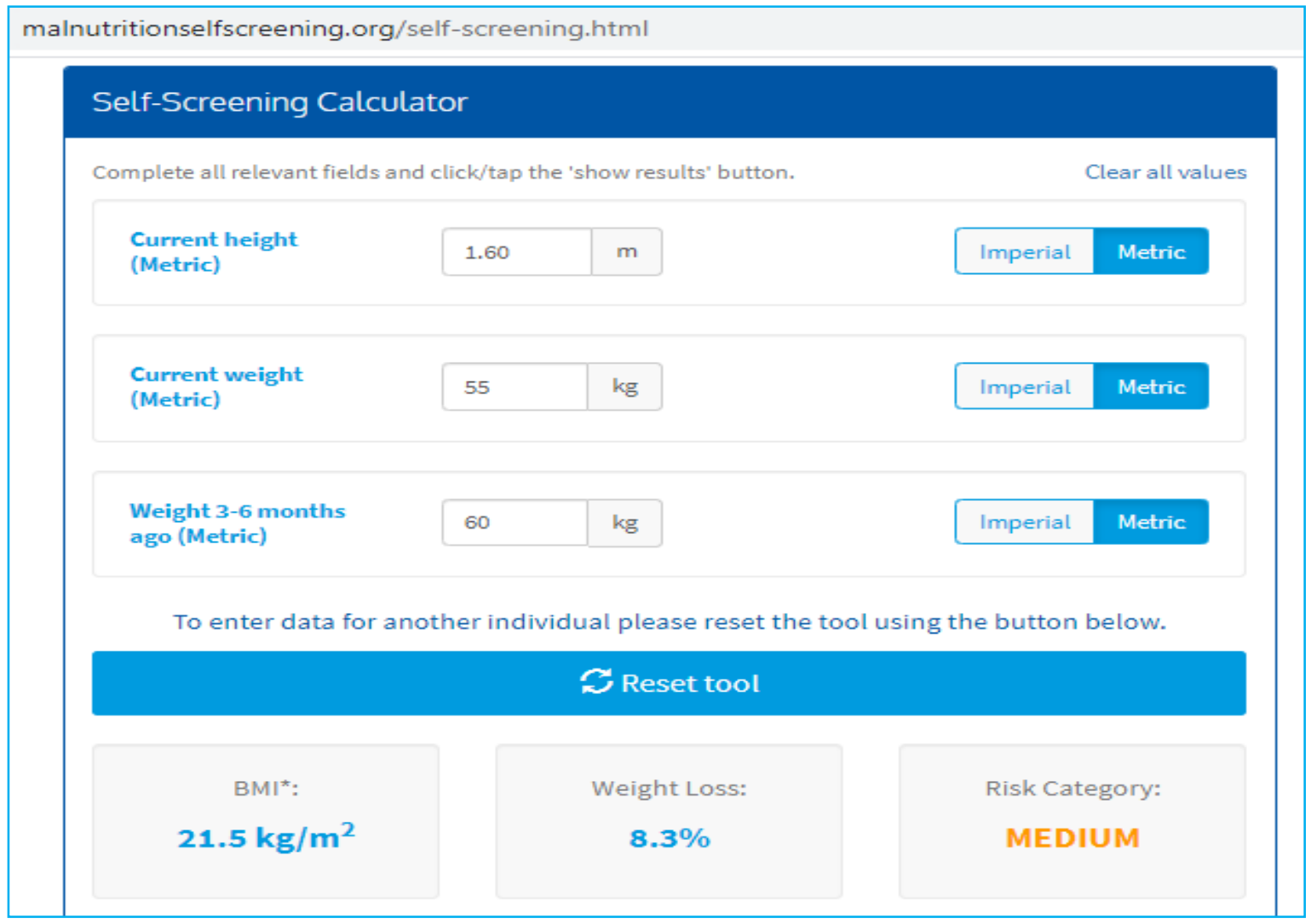

(BAPEN, Self-Screening)

Fig 2:- Online BAPEN Malnutrition Self-Screening Tool

BAPEN Malnutrition Self-Screening Tool is a free tool, easy and accessible to everyone from the Google browser, that can calculate the BMI, percentage of weight loss and the category of risk for malnutrition, based on 3 data such as: height, current weight and weight before 3-6 months.

Nutritional indicators in adults

The body mass index (BMI) is the international indicator to assess nutritional status in adults: $\mathrm{BMI}=\mathrm{Weight}(\mathrm{kg}) / \mathrm{Height}$ (m2)

Anthropometric nutritional status classification according to BMI in adults

\begin{tabular}{|c|c|}
\hline BMI & Nutritional status \\
\hline$>50 \mathrm{Kg} / \mathrm{m}^{2}$ & Type 4 obesity (extreme) \\
\hline $40-49.9 \mathrm{Kg} / \mathrm{m}^{2}$ & Type 3 obesity (morbid) \\
\hline $35-39.9 \mathrm{Kg} / \mathrm{m}^{2}$ & Type 2 obesity \\
\hline $30-34.9 \mathrm{Kg} / \mathrm{m}^{2}$ & Type 1 obesity \\
\hline $25-29.9 \mathrm{Kg} / \mathrm{m}^{2}$ & Overweight \\
\hline $18.5-24.9 \mathrm{Kg} / \mathrm{m}^{2}$ & Normal weight \\
\hline $17-18.4 \mathrm{Kg} / \mathrm{m}^{2}$ & Mild malnutrition \\
\hline $16-16.9 \mathrm{Kg} / \mathrm{m}^{2}$ & Moderate malnutrition \\
\hline$<16 \mathrm{Kg} / \mathrm{m}^{2}$ & Severe malnutrition \\
\hline
\end{tabular}

(Ministerio de Salud Peru, Instituto Nacional de Salud, 2012)

Fig 3:- Anthropometric nutritional status classification according to BMI in adults

\section{Exceptions for BMI}

- $\mathrm{BMI}$ is one of the best indicators to measure health risk

- But BMI can overestimate obesity in certain groups of people with a lot of muscle mass like some types of athletes (weight lifters)

- This scale cannot be used with pregnant or lactating women either. (INCAP, 2010) 


\section{STUDY RESULTS}

Socio-demographic characteristics of the study sample

Table 1:- Which city includes your area of residence?

\begin{tabular}{|c|c|c|}
\hline Residence & $\begin{array}{c}\text { Absolute } \\
\text { frequency }\end{array}$ & $\begin{array}{c}\text { Relative } \\
\text { frequency }\end{array}$ \\
\hline Shkodra & 1 & $0 \%$ \\
\hline Tirana & 74 & $14 \%$ \\
\hline Durresi & 6 & $1 \%$ \\
\hline Elbasani & 6 & $1 \%$ \\
\hline Fieri & 59 & $11 \%$ \\
\hline Lushnja & 34 & $6 \%$ \\
\hline Berati & 19 & $4 \%$ \\
\hline Korça & 8 & $1 \%$ \\
\hline Vlora & 302 & $55 \%$ \\
\hline Saranda & 6 & $1 \%$ \\
\hline Tepelena & 6 & $1 \%$ \\
\hline Gjirokastra & 5 & $1 \%$ \\
\hline Other City & 19 & $4 \%$ \\
\hline Total & 545 & $100 \%$ \\
\hline
\end{tabular}

\begin{tabular}{|c|c|}
\hline Total participants & 545 \\
\hline Sum & 4038.00 \\
\hline Average & 7.41 \\
\hline Standard deviation & 2.84 \\
\hline Minimum & 1.00 \\
\hline Maximum & 13.00 \\
\hline
\end{tabular}

Chart 1:- Area of residence

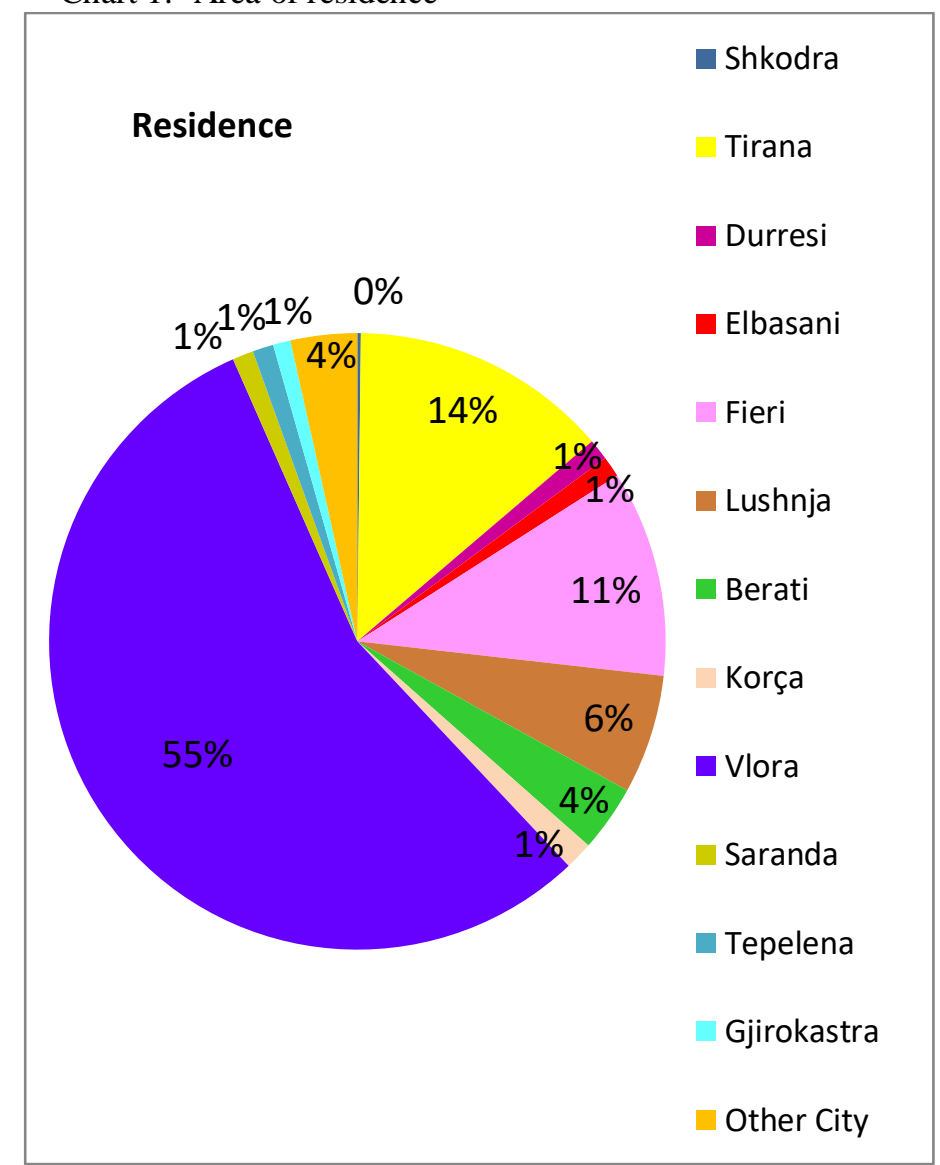

The subjects of the city of Vlora constitute the main part of the study sample, with $55 \%$.

\begin{tabular}{|c|c|c|}
\hline Gender & Absolute frequency & \multicolumn{2}{c|}{ Relative frequency } \\
\hline Woman & 410 & $25 \%$ \\
\hline Man & 135 & Relative frequency \\
\hline 8-9 year education & Absolute frequency & $5 \%$ \\
\hline Secondary education & 25 & $15 \%$ \\
\hline Professional education & 84 & $3 \%$ \\
\hline Higher education & 16 & $45 \%$ \\
\hline Master's degree & 244 & $29 \%$ \\
\hline Doctorate & 159 & $3 \%$ \\
\hline Profession & 17 & Relative frequency \\
\hline Self-employed & Absolute frequency & $9 \%$ \\
\hline Part-time employee & 51 & $6 \%$ \\
\hline Full-time employee & 34 & $38 \%$ \\
\hline Student & 206 & $35 \%$ \\
\hline Housewife & 190 & $10 \%$ \\
\hline Disabled or unable to work & 54 & $0 \%$ \\
\hline In retirement & 1 & $2 \%$ \\
\hline Total & 9 & $\mathbf{1 0 0 \%}$ \\
\hline
\end{tabular}

Table 2:- Gender, educational level and profession 
Most of the sample are women (75\%), with higher education (45\%) and master's degree (29\%), full-time employees (38\%) and students $(35 \%)$.

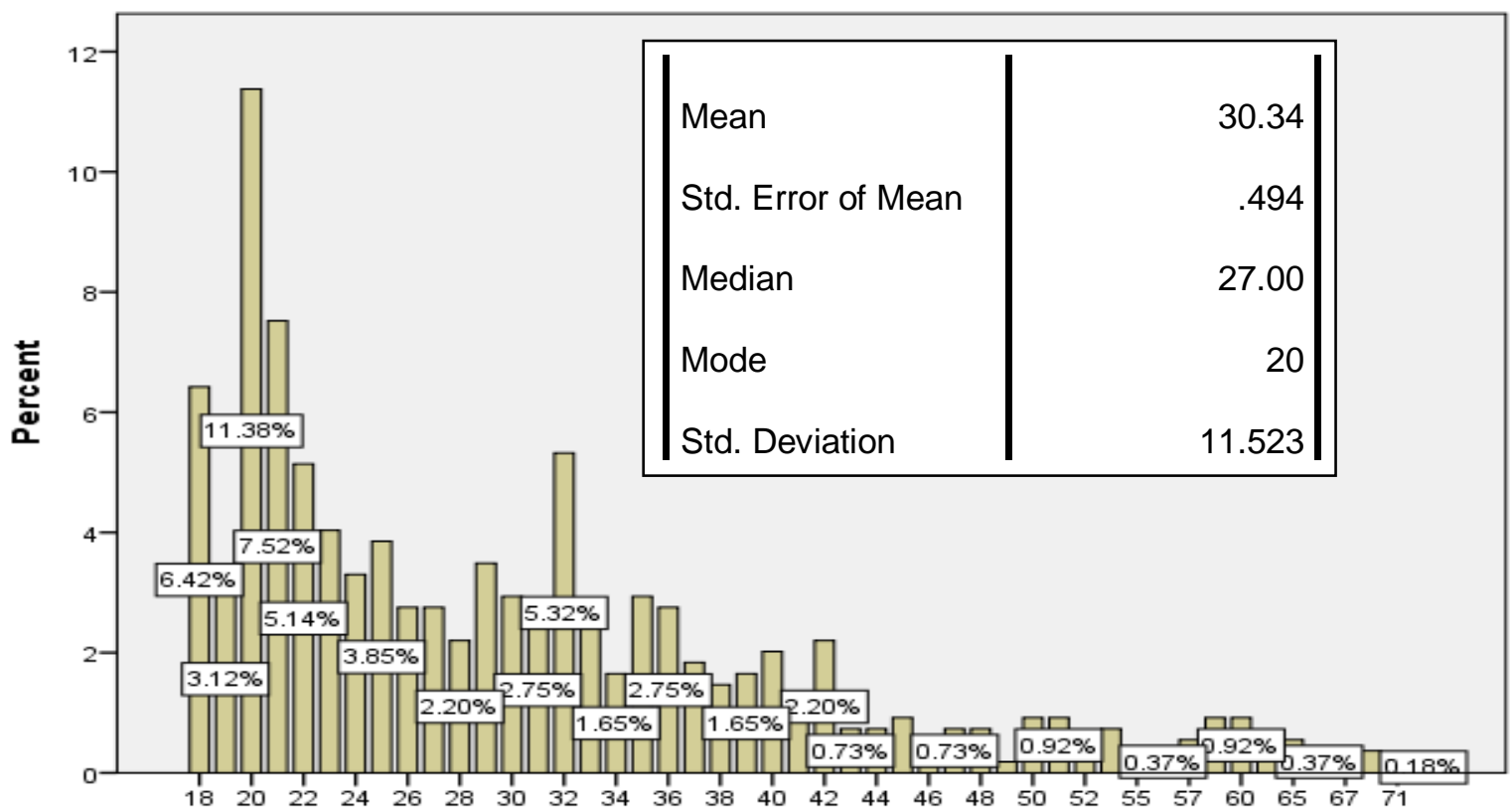

Chart 2:- Age distribution

From the chart it appears that most of the sample is of young age of 18-32 years.

Nutritional status related to BMI - AFQPHALS

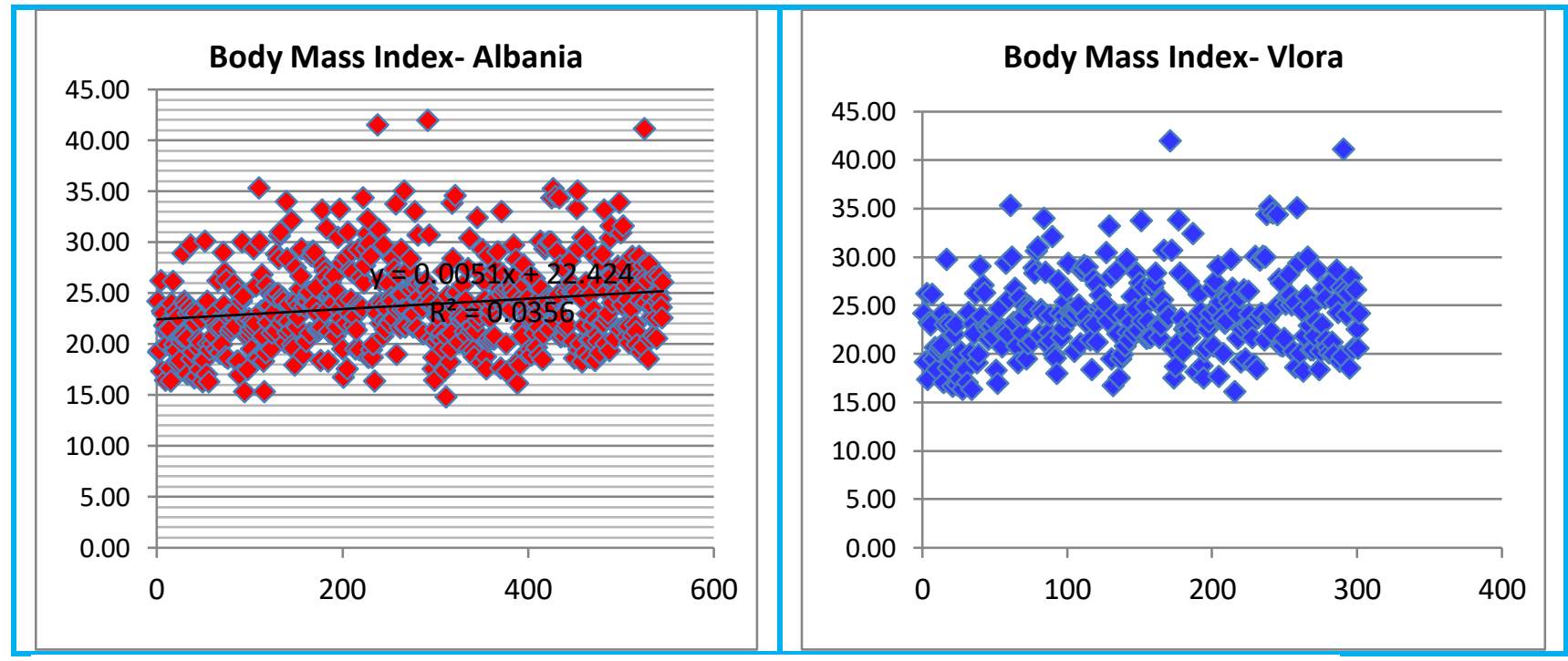

Chart 3:- Distribution of BMI in Albania

Chart 4:- Distribution of BMI in Vlora

From the charts, it turns out that the distribution of BMI in Albania and Vlora is almost the same because most of the study sample are citizens of Vlora.

In the comparative graph it turns out that the majority of subjects studied have a normal BMI (18.5-24.9). 


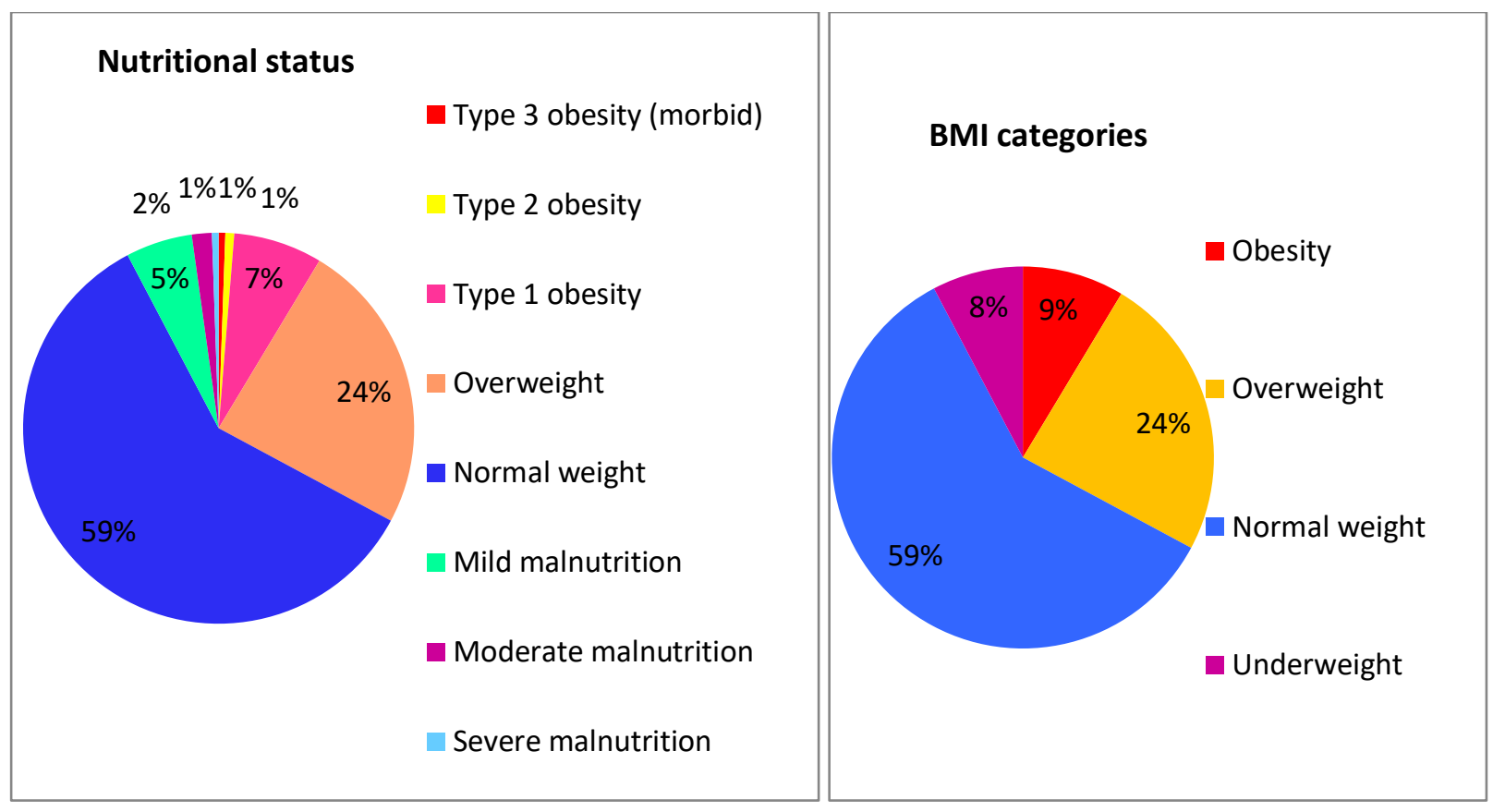

Chart 5:- Nutritional status based on BMI categories

\begin{tabular}{|c|c|c|}
\hline Severe obesity & $\mathbf{3}$ & $\mathbf{1 \%}$ \\
\hline Moderate obesity & 4 & $1 \%$ \\
\hline Mild obesity & 40 & $7 \%$ \\
\hline Overweight & 132 & $24 \%$ \\
\hline Normal weight & 324 & $59 \%$ \\
\hline Mild malnutrition & 30 & $5 \%$ \\
\hline Moderate malnutrition & 9 & $2 \%$ \\
\hline Severe malnutrition & 3 & $1 \%$ \\
\hline
\end{tabular}

\begin{tabular}{|c|c|c|}
\hline Obesity & $\mathbf{4 7}$ & $\mathbf{9 \%}$ \\
\hline Overweight & 132 & $24 \%$ \\
\hline Normal weight & 324 & $59 \%$ \\
\hline Underweight & 42 & $8 \%$ \\
\hline
\end{tabular}

Table 3:- Nutritional status related to BMI

In relation to the nutritional status based on BMI categories, we see that the majority of the subjects studied were of normal weight with $59 \%$, followed by overweight with $24 \%$, mild obesity $7 \%$, mild malnutrition with $5 \%$, moderate malnutrition with 2 $\%$, severe malnutrition, moderate obesity and severe obesity with $1 \%$.

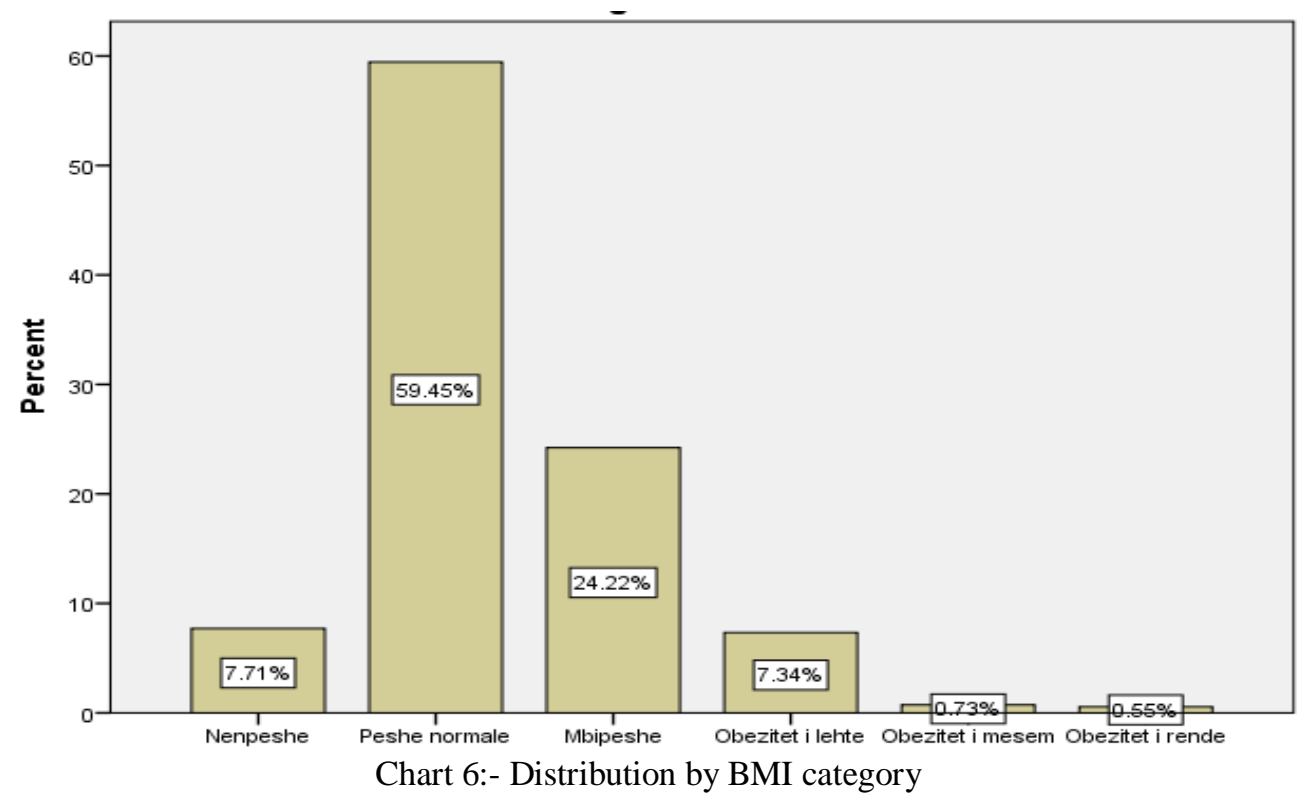


From the chart it turns out that most of the sample is from the BMI normal weight category (59\%), 24\% overweight, $9 \%$ obesity and $8 \%$ underweight.
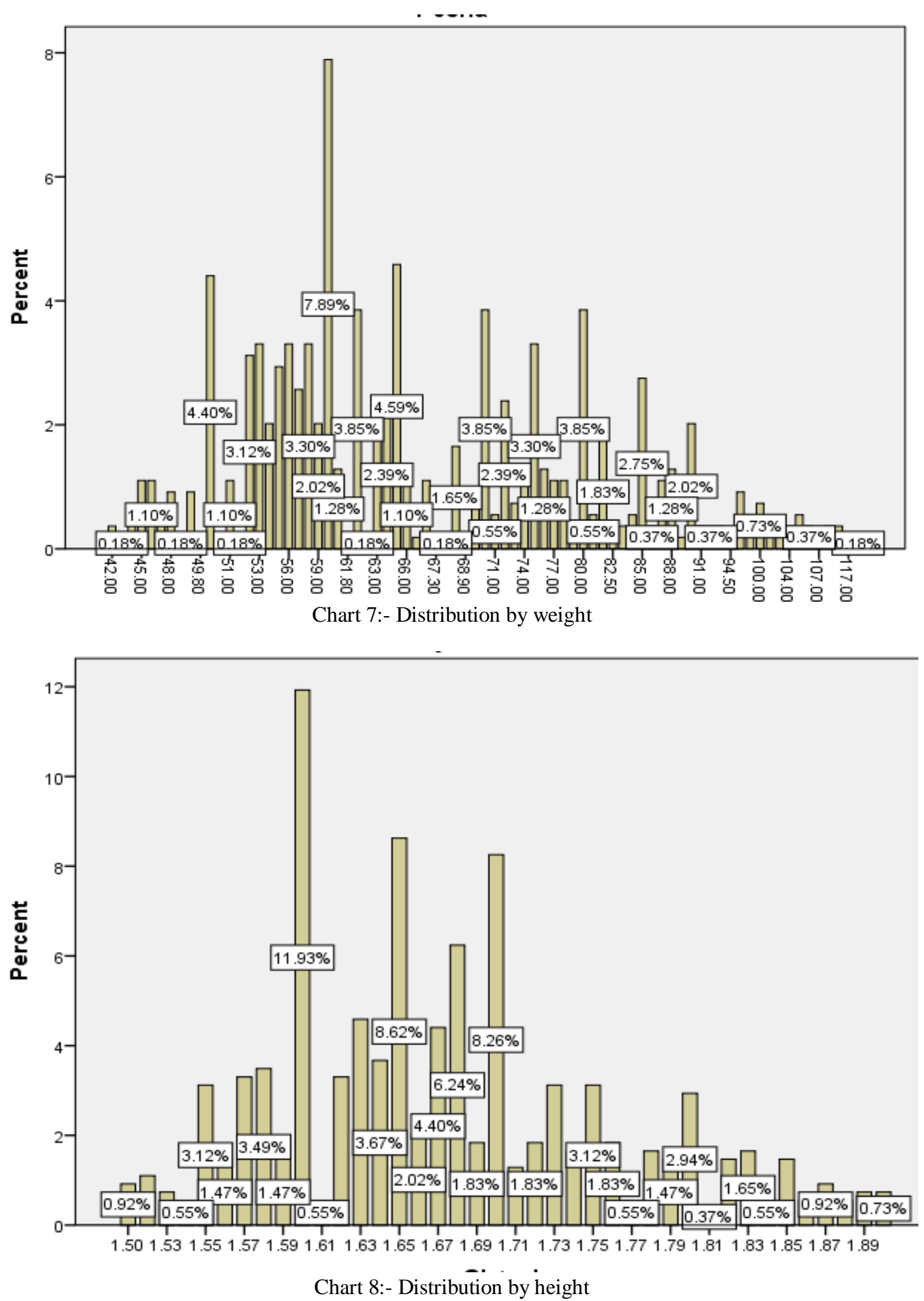
The level of risk of malnutrition - AFQPHALS

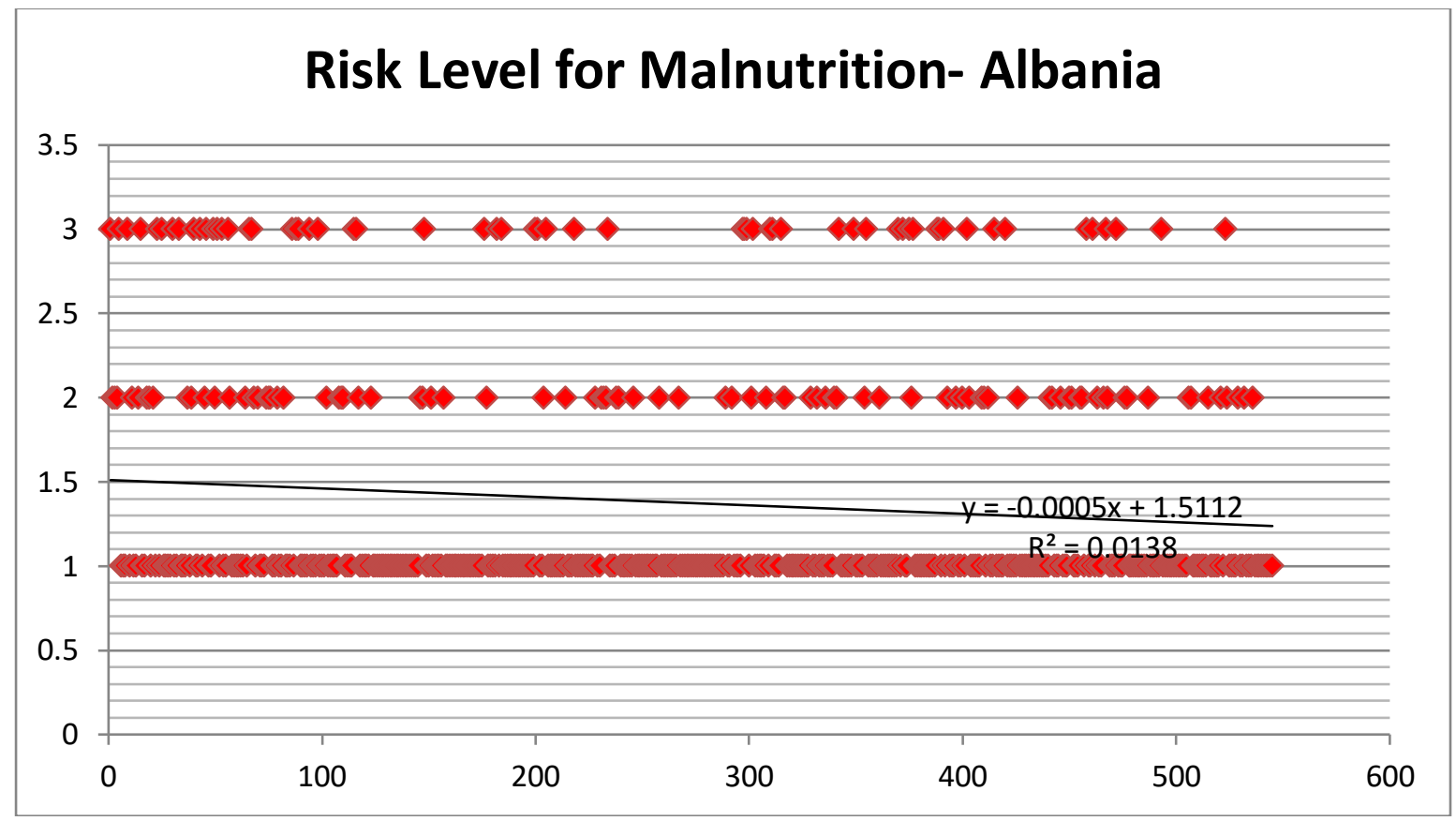

Chart 9:- Risk level for malnutrition - Albania

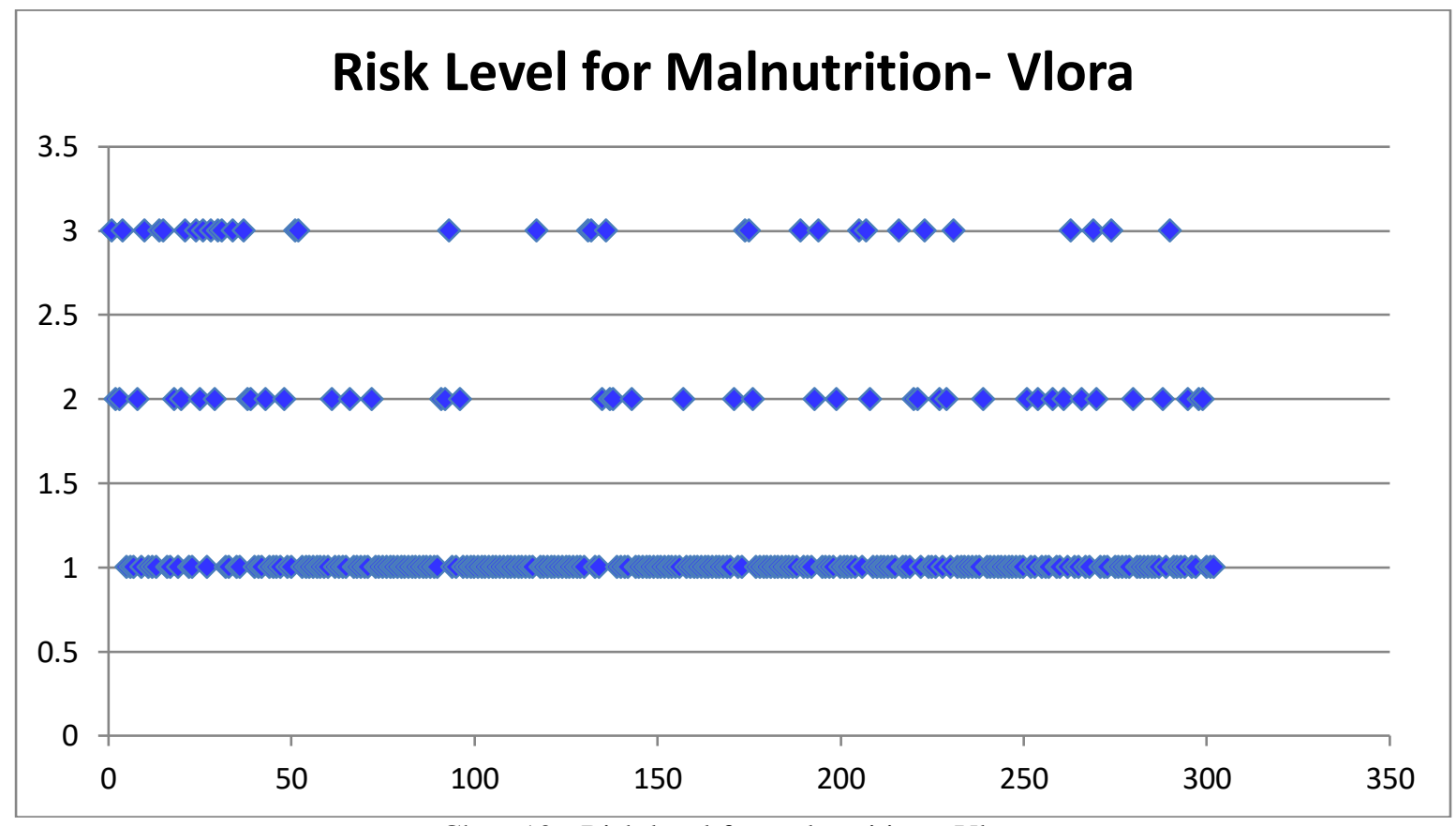

Chart 10:- Risk level for malnutrition - Vlora

From the charts (Albania and Vlora) results that the major part of the study sample has a low level (1) risk of malnutrition, but a part of the sample has medium level (2) and high level (3) of malnutrition.

\begin{tabular}{|c|c|c|c|c|c|}
\hline \multicolumn{7}{|c|}{ Risk level for malnutrition } \\
\hline \multirow{3}{*}{ Valid } & Low risk & Frequency & Percent & Valid Percent & Cumulative Percent \\
\cline { 2 - 7 } & Medium risk & 400 & 73.4 & 73.4 & 73.4 \\
\cline { 2 - 6 } & High risk & 56 & 15.8 & 15.8 & 89.2 \\
\cline { 2 - 6 } & Total & 545 & 100.8 & 10.8 & 100.0 \\
& & & 100.0 & \\
\end{tabular}

Table 4:- Risk level for malnutrition 
ISSN No:-2456-2165

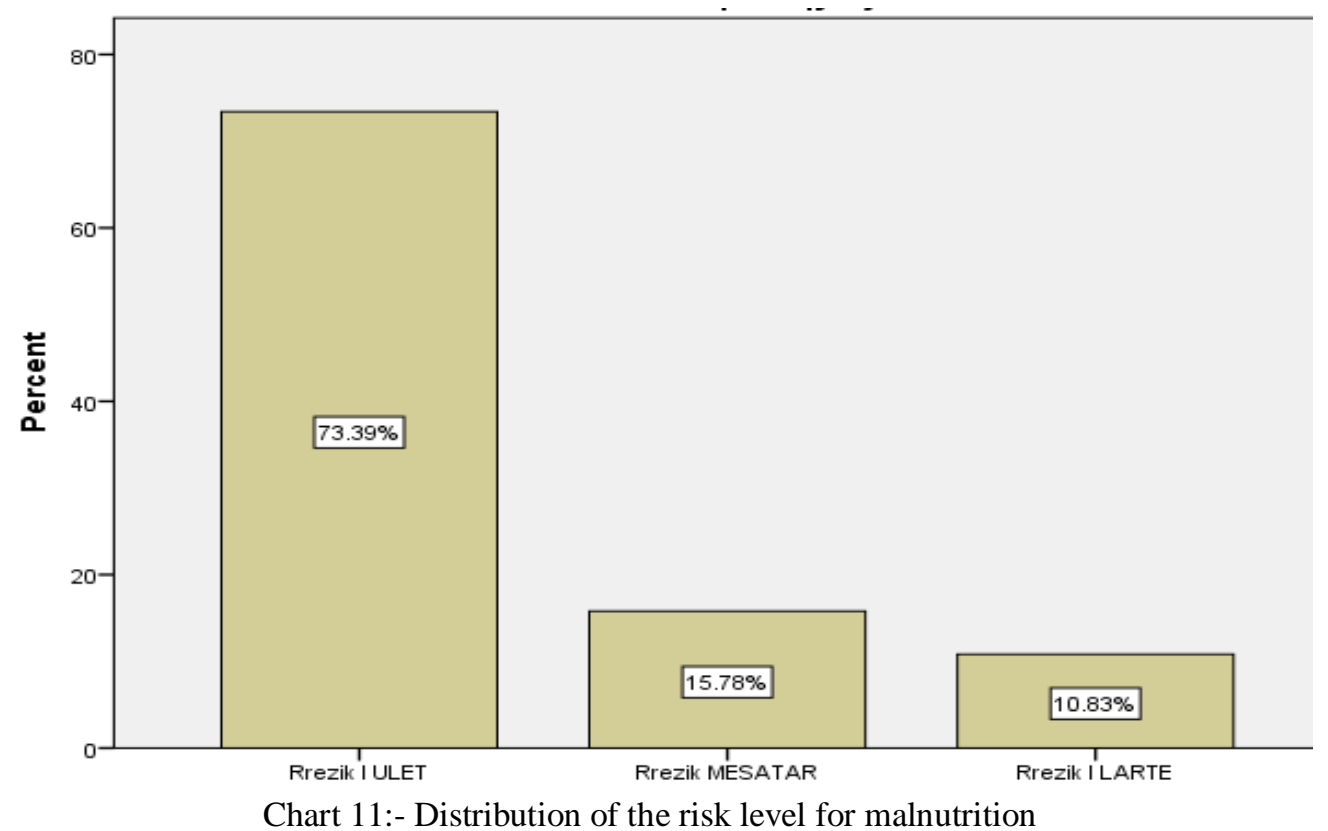

From the table 4 and chart 11 results that, $73 \%$ of the study sample has low risk, $16 \%$ has medium risk and $11 \%$ has high risk for malnutrition.

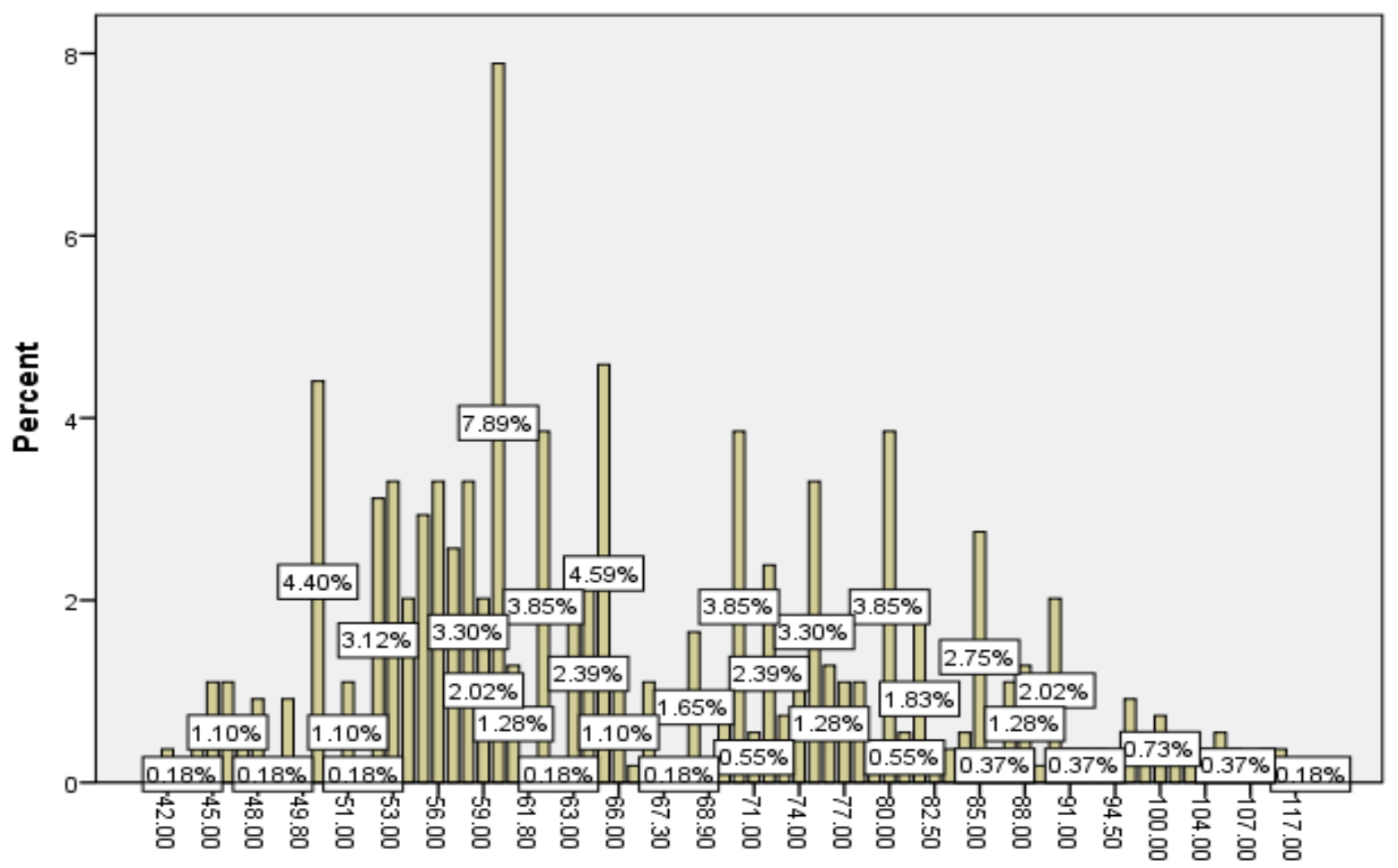

Chart 12:- Distribution by weight 


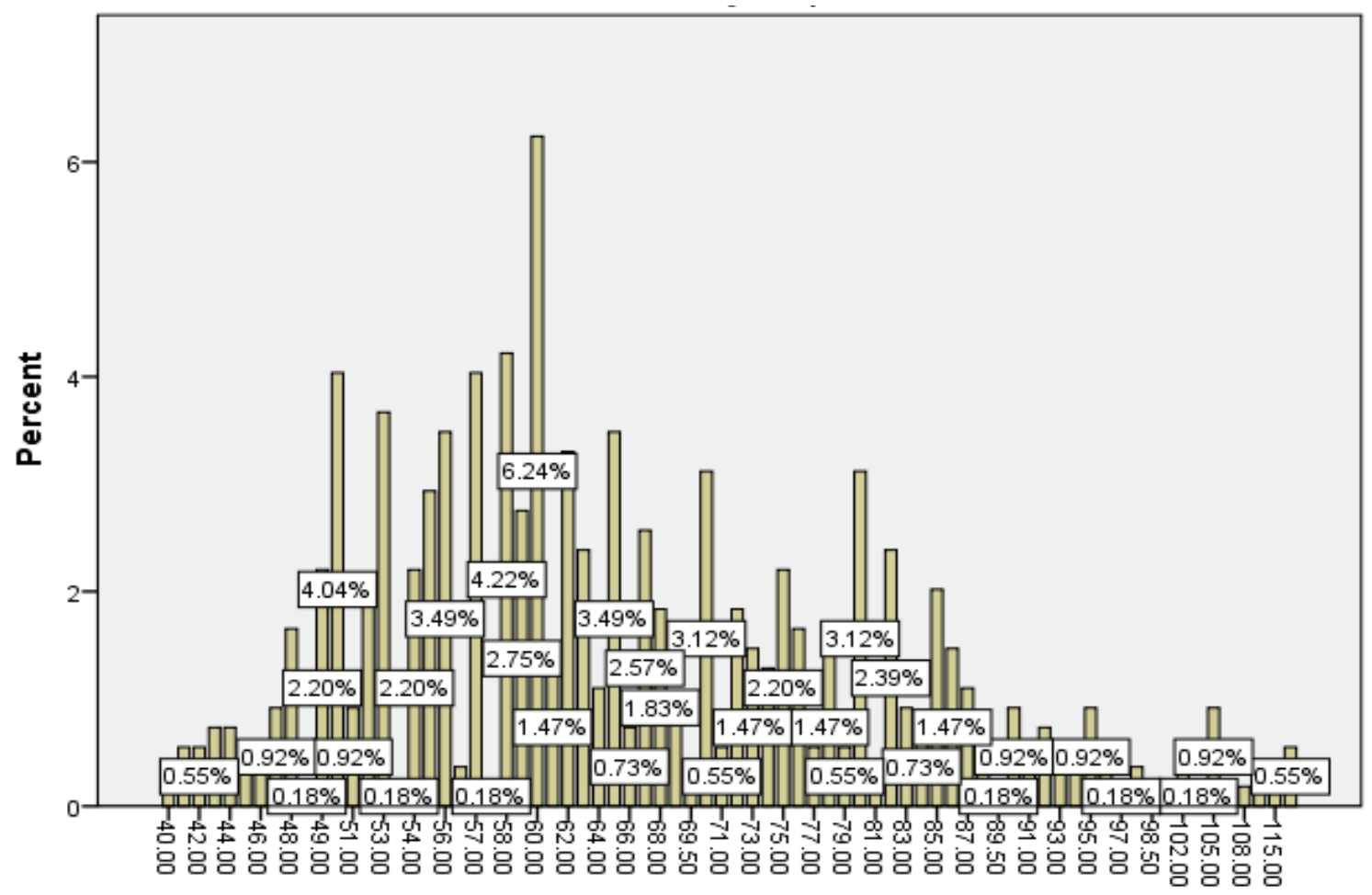

Chart 13:- Distribution by weight before 3- 6 months

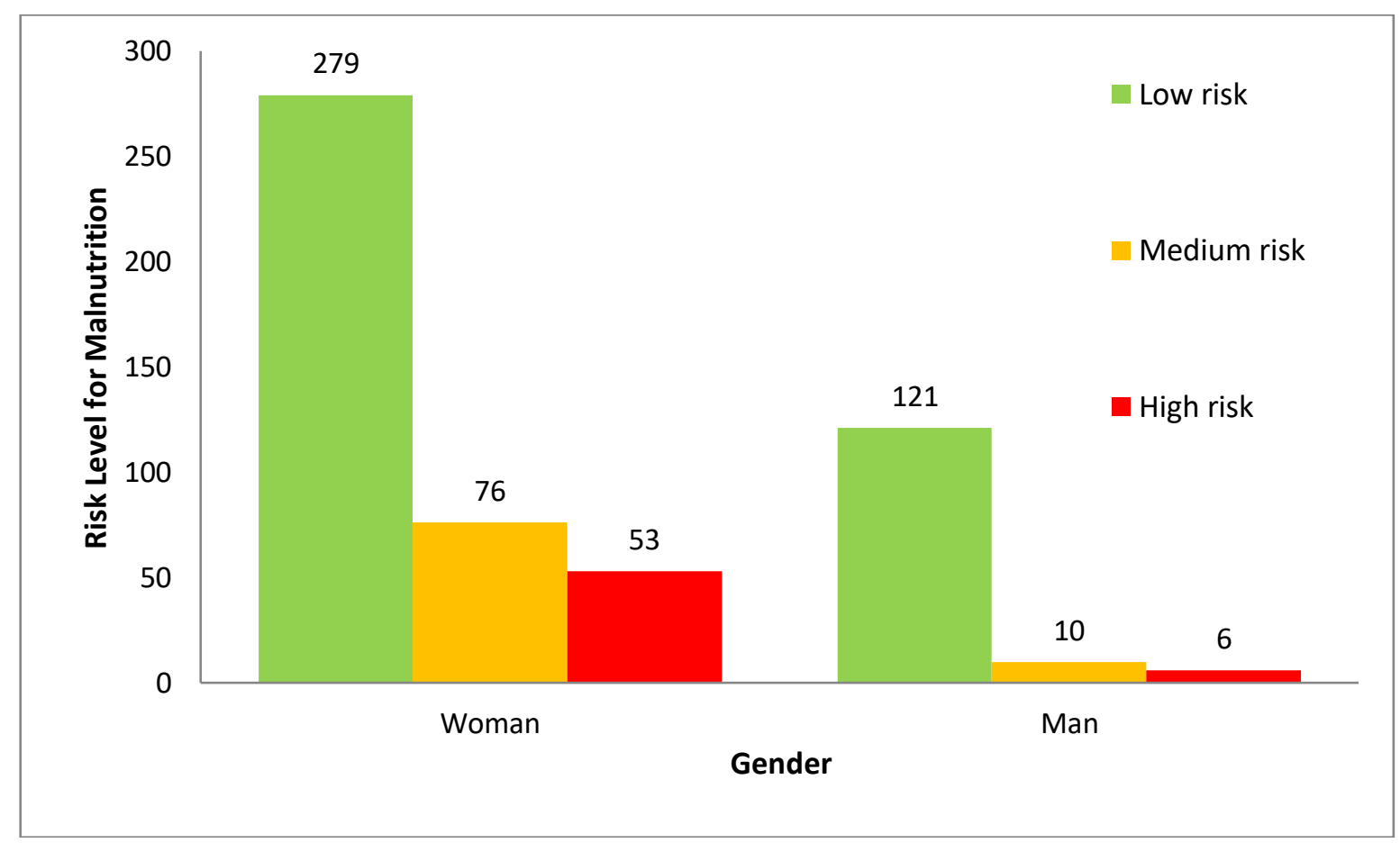

Chart 14:- Distribution of risk of malnutrition according to gender

The chart shows that there are statistically significant differences between the risk of malnutrition and gender ( $\mathrm{p}<0.005)$. The risk of malnutrition in women predominates (low, medium and high risk). 
ISSN No:-2456-2165

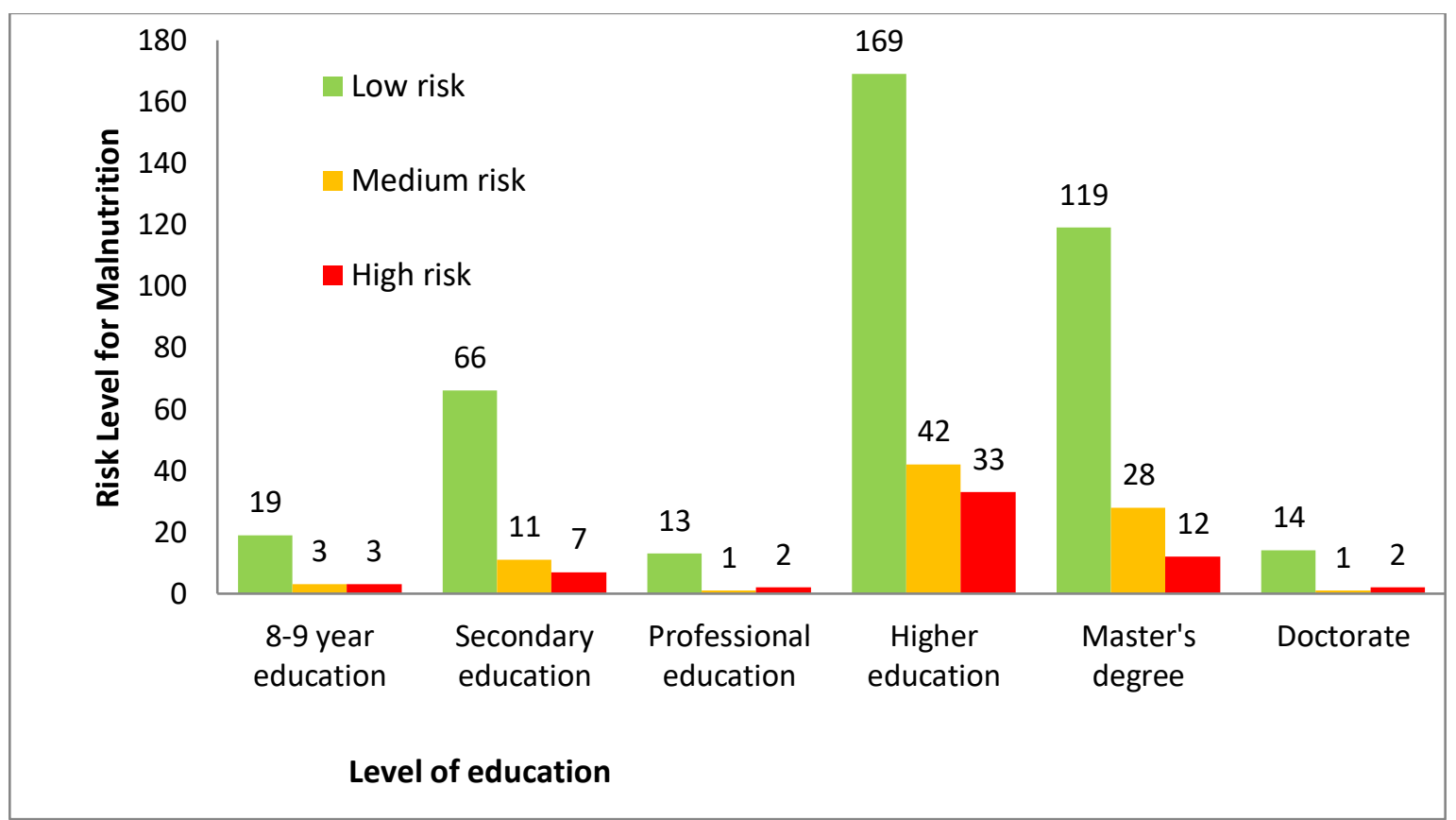

Chart 15:- Malnutrition risk distribution according to level of education

The chart shows that there are no statistically significant differences between the risk of malnutrition and level of education ( $\mathrm{p}<0.005)$. Low risk prevails in all professions, and medium risk and high risk prevails at higher education and master's level.

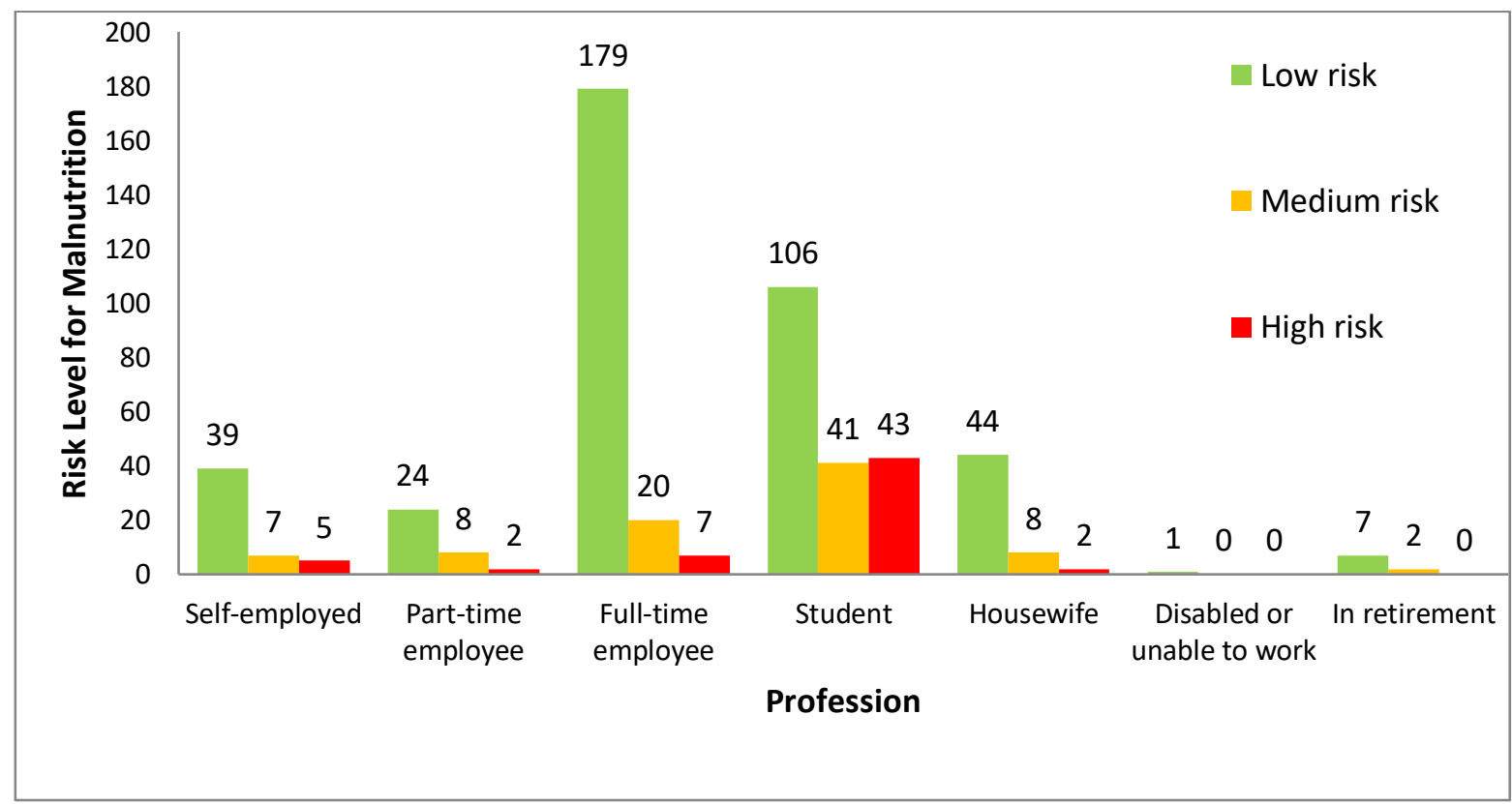

Chart 16:- Malnutrition risk distribution according to profession

The chart shows that there are statistically significant differences between risk of malnutrition and profession ( $\mathrm{p}<0.005$ ). Low risk prevails in all professions, medium risk and high risk prevails in students and full-time employees.

The high risk of malnutrition is associated with the student profession. 
Weight Loss Percentage - AFQPHALS

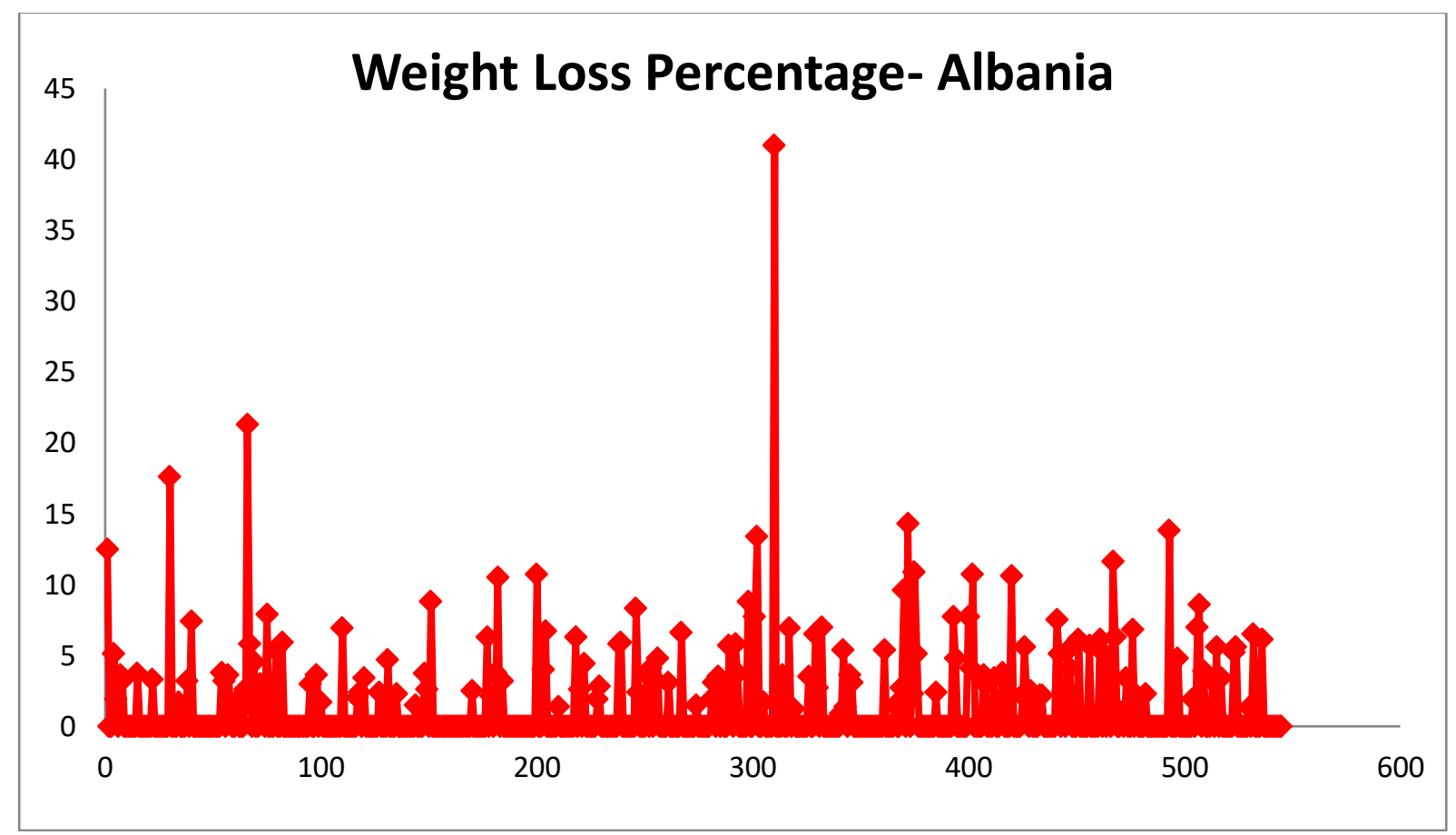

Chart 17:- Weight Loss Percentage Distribution - Albania

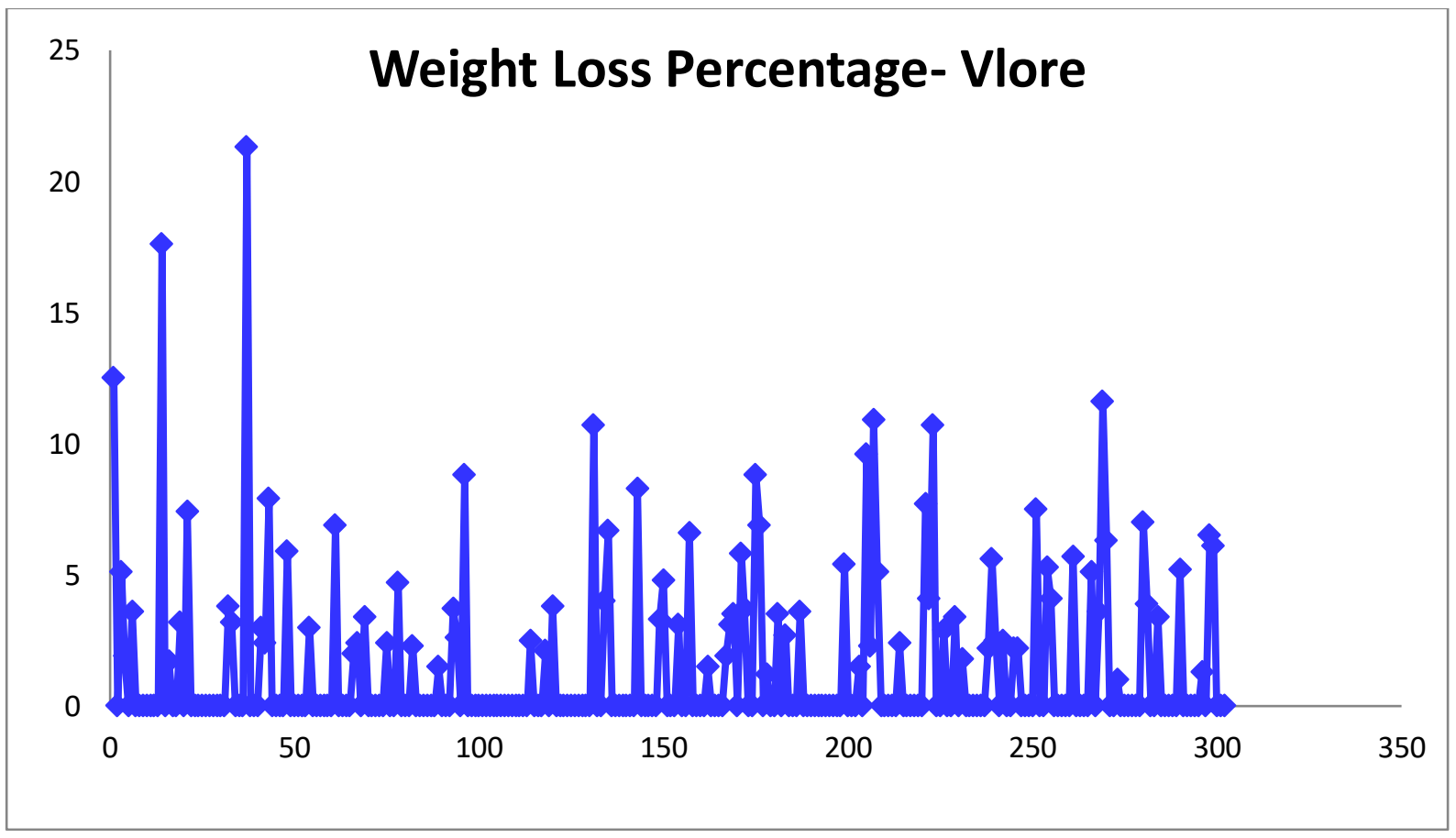

Chart 18:- Weight Loss Percentage Distribution - Vlora

From the graph (Albania and Vlora) it appears that most of the study sample $(73 \%)$ has not lost weight $0 \%,(\mathrm{mean}=1.3657$, median $=.0000$, mode $=.000$ and Std. Deviation $=3.21498)$. 
ISSN No:-2456-2165

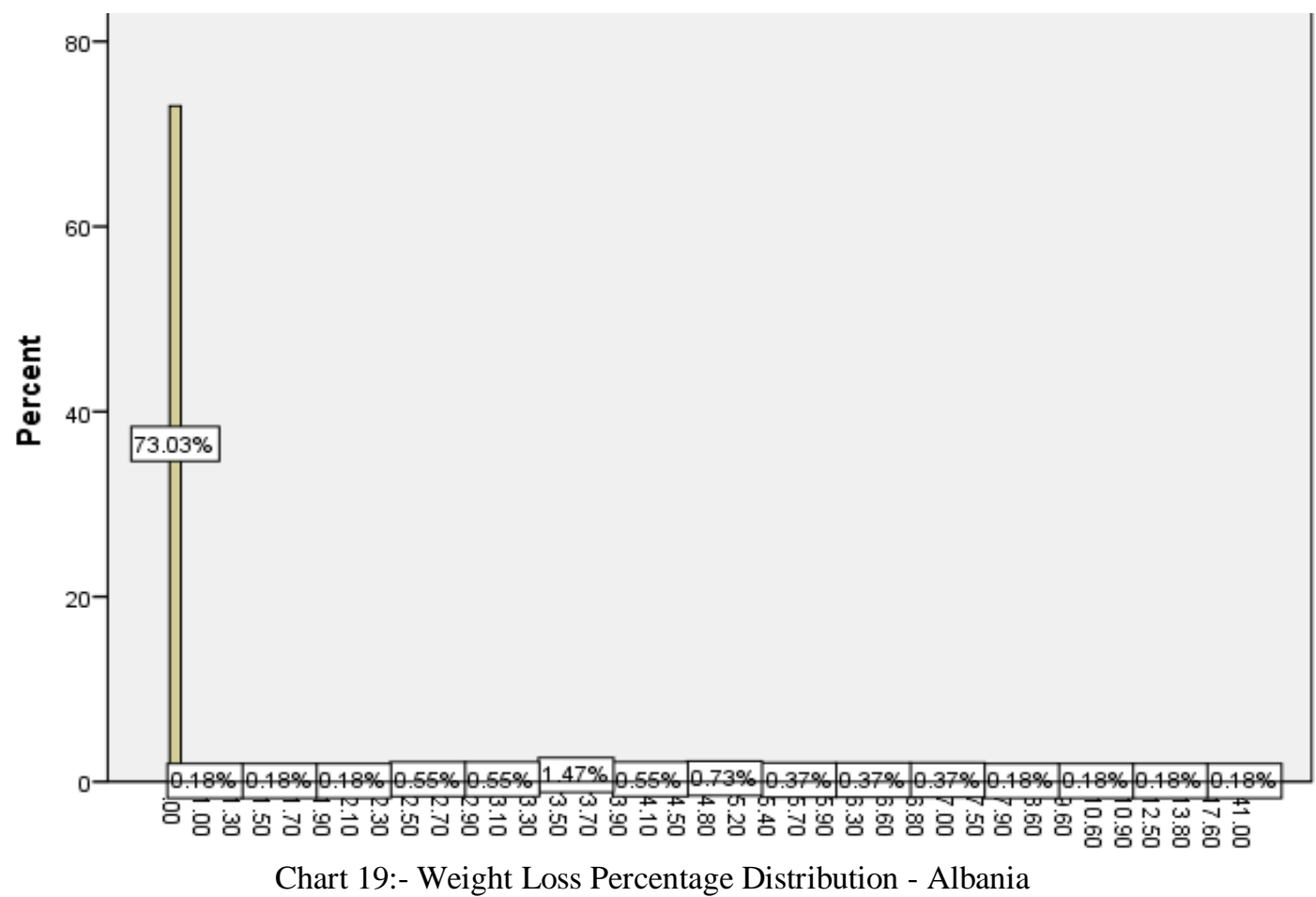

The chart show that $73 \%$ of study sample has not lost weight.

\section{CONCLUSIONS}

The subjects of the city of Vlora constitute the main part of the study sample, with $55 \%$.

Most of the sample are women (75\%), with higher education (45\%) and master's degree (29\%), full-time employees (38\%) and students (35\%).

Most of the sample is of young age of 18-32 years.

$>$ The distribution of BMI in Albania and Vlora is almost the same because most of the study sample are citizens of Vlora.

In relation to the nutritional status based on BMI categories, we see that the majority of the subjects studied were of normal weight with $59 \%$, followed by overweight with $24 \%$, mild obesity $7 \%$, mild malnutrition with $5 \%$, moderate malnutrition with $2 \%$, severe malnutrition, moderate obesity and severe obesity with $1 \%$.

Most of the sample is from the BMI normal weight category (59\%), 24\% overweight, $9 \%$ obesity and $8 \%$ underweight.

$>$ In Albania and Vlora results that the major part of the study sample has a low level (1) risk of malnutrition, but a part of the sample has medium level (2) and high level (3) of malnutrition.

$73 \%$ of the study sample has low risk, $16 \%$ has medium risk and $11 \%$ has high risk for malnutrition.

$>$ In Albania and Vlora it appears that most of the study sample $(73 \%)$ has not lost weight $0 \%$, (mean $=1.3657$, median $=.0000$, mode $=.000$ and Std. Deviation $=$ 3.21498).

The high risk for malnutrition according to gender, level of education and profession, prevails in gender female, at higher education and master's level in students and full-time employees.

The 'MUST' is a good tool to discover subjects with different levels of risk, also in the BMI categories normal weight or overweight, from height, current weight and weight before 3- 6 months.

\section{REFERENCES}

[1]. Abbie L. Cawood, E. R. (2018). 'Self-screening' for malnutrition with an electronic version of the Malnutrition Universal Screening Tool ('MUST') in hospital outpatients: concurrent validity, preference and ease of use. British Journal of Nutrition , 528536.

[2]. Álvarez Ochoa, R. I., del Rosario Cordero Cordero, G., Vásquez Calle, M. A., Altamirano Cordero, L. C., \& Gualpa Lema, M. C. (2017, nov-dic). Hábitos alimentarios, su relación con el estado nutricional en escolares de la ciudad de Azogues. Retrieved 6 25, 2020, from http://scielo.sld.cu/: http://scielo.sld.cu/scielo.php?script=sci_arttext\&pid= S1561-31942017000600011

[3]. BancoMundial. (2018, Sep 28). Nutrición. Retrieved 2 11, 2020, from https://www.bancomundial.org: https://www.bancomundial.org/es/topic/nutrition/over view

[4]. BAPEN. (2018, May 27). BAPEN Malnutrition SelfScreening Tool. Retrieved from https://www.bapen.org.uk/: https://www.bapen.org.uk/screening-andmust/malnutrition-self-screening-tool

[5]. BAPEN. (n.d.). 'Malnutrition Universal Screening Tool'. Retrieved from https://www.hse.ie/: 
https://www.hse.ie/eng/staff/pcrs/onlineservices/musttool.pdf

[6]. BAPEN. (n.d.). Self-Screening. Retrieved from https://www.malnutritionselfscreening.org/: https://www.malnutritionselfscreening.org/selfscreening.html

[7]. BAPEN, Self-Screening. (n.d.). Retrieved 2020, from https://www.malnutritionselfscreening.org/: https://www.malnutritionselfscreening.org/selfscreening.html

[8]. Carbajal Azcona, Á. (2013, Septiembre). Manual de Nutrición y Dietética. Retrieved mayo 21, 2020, from https://eprints.ucm.es/:

https://eprints.ucm.es/22755/1/Manual-nutriciondietetica-CARBAJAL.pdf

[9]. Cawood, Abbie \& Walters, Emily \& Sharp, Sarah \& Elia, Marinos \& Stratton, Rebecca. (2018). 'Selfscreening' for malnutrition with an electronic version of the Malnutrition Universal Screening Tool ('MUST') in hospital outpatients: Concurrent validity, preference and ease of use. British Journal of Nutrition. 120. 1-9. 10.1017/S000711451800185X. DA SILVA, J. G. (2016, Oct 14). La malnutrición es un problema de todos. Retrieved 2 11, 2020, from https://elpais.com:

https://elpais.com/elpais/2016/10/10/planeta_futuro/1 476085010_698627.html

[10]. Durán, S. (2017, Nov). Validación de contenido de la Encuesta de Calidad de Alimentación del Adulto Mayor (ECAAM). Retrieved 2 11, 2020, from https://www.researchgate.net:

https://www.researchgate.net/publication/321060959_ Validacion_de_contenido_de_la_Encuesta_de_Calida d_de_Alimentacion_del_Adulto_Mayor_ECAAM

[11]. FAO. (2007, oct 9). Buenos hábitos alimentarios contra la malnutrición y las enfermedades relacionadas con la dieta. Retrieved 6 25, 2020, from http://www.fao.org/newsroom/es/news/2007/1000673/ index.html:

http://www.fao.org/newsroom/es/news/2007/1000673/ index.html

[12]. FAO. (2014, Nov 19-21). Por qué la nutrición es importante. Retrieved 2 11, 2020, from http://www.fao.org: http://www.fao.org/3/aas603s.pdf

[13]. FAO. (2014, nov 19-21). Por qué la nutrición. ¿QUÉ ES MALNUTRICIÓN? Retrieved jun 25, 2020, from http://www.fao.org/: $\quad$ http://www.fao.org/3/aas603s.pdf

[14]. INCAP. (2010, Agosto 9 - 13). Evaluación del estado nutricional . Retrieved 06 24, 2020, from https://www.paho.org/:

https://www.paho.org/hon/index.php?option=com_do cman\&view=download\&alias=209-evaluacion-delestado-nutricional\&category_slug=desarrollohumano-sostenible-y-estilos-de-vida-sal\&Itemid=211

[15]. Malnutrition Task Force. (n.d.). Self-Screening Resource Pack. Retrieved from https://www.malnutritiontaskforce.org.uk/: https://www.malnutritiontaskforce.org.uk/resourcesand-tools/self-screening-resource-pack
[16]. Ministerio de Salud Peru, Instituto Nacional de Salud. (2012). Tabla de valoracion nutricional segun IMC adultas/os. Retrieved 7 11, 2020, from https://bvs.ins.gob.pe/:

https://bvs.ins.gob.pe/insprint/CENAN/Tabla_valor_n utricional_segun_IMC_adultos.pdf

[17]. Ministria e Shendetesise. (2017). PLANI I VEPRIMIT TË PROMOCIONIT SHËNDETËSOR 2017-2021. Retrieved 2020, from http://www.ishp.gov.al/: http://www.ishp.gov.al/wpcontent/uploads/2017/05/PLANI-VEPRIMIT-PROMSHEND_2017-2021.pdf

[18].NHS. (n.d.). Malnutrition Universal Screening Tool ('MUST'). Retrieved from https://www.bfwh.nhs.uk/: https://www.bfwh.nhs.uk/ourservices/community-nutrition-anddietetics/nutritional-support/

[19]. NMAS1. (2019, abril 04). Los malos hábitos alimenticios ya causan 1 de cada 5 muertes en el mundo. Retrieved 6 25, 2020, from https://nmas1.org/: https://nmas1.org/news/2019/04/04/dietadesbalanceada-muerte

[20]. OMS. (1963, dic). L,A MALNUTRICION Y LOS HABITOS ALIMENTARIOS. Retrieved 6 25, 2020, from https://iris.paho.org/: https://iris.paho.org/bitstream/handle/10665.2/1131/S P91.pdf? sequence $=1 \&$ isAllowed $=\mathrm{y}$

[21]. OMS. (2012). LA BUENA SALUD AÑADE VIDA A LOS ANOS. Retrieved 2020, from https://apps.who.int/:

https://apps.who.int/iris/bitstream/handle/10665/7525 4/WHO_DCO_WHD_2012.2_spa.pdf;jsessionid=9B A5D3779D36C0BF576BE7277D9CB9F1?sequence= 1

[22]. OMS. (2019, september 26). Malnutrition is a world health crisis. Retrieved june 25, 2020, from https://www.who.int/news-room/detail/26-09-2019malnutrition-is-a-world-health-crisiss: https://www.who.int/news-room/detail/26-09-2019malnutrition-is-a-world-health-crisiss

[23]. WHO. (2018, 2 16). Malnutrición. Retrieved 2 11, 2020, from https://www.who.int: https://www.who.int/es/news-room/factsheets/detail/malnutrition

[24]. WHO. (2020, abril 1). Malnutrición. Retrieved junio 23, 2020, from https://www.who.int/es/: https://www.who.int/es/news-room/factsheets/detail/malnutrition

[25]. WHO. (1963). MALNUTRICION Y ENFERMEDAD . Retrieved 2 15, 2020, from https://apps.who.int: https://apps.who.int/iris/bitstream/handle/10665/1057 24/a58435_spa.pdf;jsessionid=0961A3E7B9D4163FE 2D232ECB9540396? sequence $=1$

[26]. WHO, FAO. (2003). DIETA, NUTRICIÓN Y PREVENCIÓN DE ENFERMEDADES CRÓNICAS. Retrieved 2 11, 2020, from http://www.fao.org: http://www.fao.org/3/a-ac911s.pdf 